\title{
Speaking Skills: What Arabic Language Students Do in Simulation Activity?
}

\author{
Azman Che Mat ${ }^{1, *}$, Ahmad Fakrulazizi Abu Bakar², Ahmad Zulfadhli Nokman', \\ Nor Shaifura Musilehat ${ }^{2}$, Norhayuza Mohamad ${ }^{3}$ \\ ${ }^{1}$ Academy of Language Studies, MARA University of Technology Malaysia (UiTM) Campus of Dungun, Sura Hujung, 23000 \\ Dungun, Terengganu, Malaysia \\ ${ }^{2}$ Academy of Language Studies, MARA University of Technology Malaysia (UiTM) Campus of Kuala Terengganu, 21080 Kuala \\ Terengganu, Terengganu, Malaysia \\ ${ }^{3}$ Academy of Language Studies, MARA University of Technology Malaysia (UiTM) Shah Alam, Malaysia
}

Received August 13, 2020; Revised October 18, 2020; Accepted October 24, 2020

\section{Cite This Paper in the following Citation Styles}

(a): [1] Azman Che Mat, Ahmad Fakrulazizi Abu Bakar, Ahmad Zulfadhli Nokman, Nor Shaifura Musilehat, Norhayuza Mohamad , "Speaking Skills: What Arabic Language Students Do in Simulation Activity?," Universal Journal of Educational Research, Vol. 8, No. 12, pp. 6998 - 7005, 2020. DOI: 10.13189/ujer.2020.081267.

(b): Azman Che Mat, Ahmad Fakrulazizi Abu Bakar, Ahmad Zulfadhli Nokman, Nor Shaifura Musilehat, Norhayuza Mohamad (2020). Speaking Skills: What Arabic Language Students Do in Simulation Activity?. Universal Journal of Educational Research, 8(12), 6998 - 7005. DOI: 10.13189/ujer.2020.081267.

Copyright $\subseteq 2020$ by authors, all rights reserved. Authors agree that this article remains permanently open access under the terms of the Creative Commons Attribution License 4.0 International License

\begin{abstract}
Language skills, especially speaking skills, are necessary for mastering of a foreign language. Many strategies were applied in class setting to achieve the skills with several activities. Many researchers have suggested various activities to develop speaking skills for Arabic language. Among these activities are drama, role play, simulation etc. Each activity has different execution to meet the objective of language learning. This study aims to explore the strategies of Arabic language speaking skills among students through paired simulation activities. The qualitative approach is fully utilized through journal notes and observation check list. Four Arabic lecturers were involved in journal notes relating to their observations of strategies used by students in general. Meanwhile, a total of 12 respondents were selected by observing their simulation performances, especially in terms of language items. Then descriptive analysis was carried out to stipulate the data with the concentration on learning strategies for speaking skills of the students and language performance regarding the use of speaking Arabic during simulation activity. This study generally found that Arabic language learners practice speaking skills with the support of other strategies such as memory, writing and reading strategies. Meanwhile linguistics items produced by respondents in the activity have common errors including lexical choice, grammatical structure and morphological aspect. In the
\end{abstract}

nutshell, simulation activity has significantly affected on students learning strategy and provides essential information for Arabic language lecturers to assist their students in improving their language performance especially speaking skills.

Keywords Strategy, Speaking, Simulation, Arabic

\section{Introduction}

Speaking skills are one of the most important language skills. Basically, studies on speaking skills are known as oral approaches that emphasize the ability to speak a language. This speaking approach continues to evolve with the emergence of communicative approaches that also emphasize oral skills in language learning [10]. One of the suggested activities in the communicative approach is simulation activities. Wan Hasmah Wan Mamat and Nur Munirah Teoh Abdullah [16] asserted that simulation games help teachers and students to interact as well as enliven the learning environment. In countries like China and Japan, language teachers encourage students to participate in, for example role plays, etc. [5]. In Malaysia, the familiar practice was carried out in foreign language 
class setting whenever speaking skills becomes the focus of teaching and learning outcomes.

In this article, the case at UiTM became the focus of the study. Paired simulation is a language activity that uses dialogue techniques between two individuals. Only two students were involved as a pair in this activity for a minimum ten phrases for each partner. Before students embark on simulation, each pair will prepare for performances such as drafting a dialogue, scenes setting and characters role. Students must use learning skills to gather information, organize information, construct stories and write dialogues. After that, they will practice the dialogue smoothly and make the simulation becomes authentic language setting.

\subsection{Simulation Activity}

As mentioned by Khrasen (as cited in Mohd Azan Nair, 2000), adult language learners tend to learn consciously compared to child learners. Nevertheless, this difference does not prevent both groups from language learning and achieve considerable attainment [19]. Thus, adult learners need more conducive environments to be created to assist them in acquiring language skills, especially speaking skills. Then it becomes vital for teachers to identify students' backgrounds and determine the objective of teaching and learning and provide practical activities within their capacity such as applicable, suitable for student level, full involvement, doable for every stage, related to their syllabus and attractive to all students [9, 20].

Many researchers have suggested various activities to develop speaking skills for Arabic language. However, to be specific on adult learners, some activities are not appropriate due to the time constrains and the level of challenges. Responding to this notion, Khalilullah [15] has outlined three principles to assist adult students learning of language:

1. Student has to be conscious that he/she is learning and then develops motivation to acquire language competency successfully;

2. Learning outcomes are only success through process, which does not happen spontaneously. It is a consistent and gradually process;

3. Students need an active interaction as a human; they will develop fast if given a support and assistant from their teachers, facilitators or lecturers.

One of the language activities is simulation which could be perceived as a part of drama and role play. In language learning, drama and role play accumulate many benefits to students beyond their language acquisition. It is proved that role-playing based learning activities can improve learners' speaking and writing skills through peer-to-peer and self-correction behavior [33]. Drama and role play are also applicable in another subject to strengthen social skills and its values such as cooperative, readiness, planning and so on. Brown [7] and Kayi [14] differentiated simulation and role play noting that role plays are more elaborate whereby simulation is simple in simulations; students can bring items to the class to create a realistic environment. While Javid [13] wrote that simulation refers to the act of imitating the behavior of some situations or some process by means of something suitably analogous.

In this study, simulation activity is defined as "an imitation of certain situation using dialog between students with a short period which created a real situation to perform speaking skills among language learners.” From several readings on proposed activities for Arabic language teaching and learning, researchers have identified similar activities such as "Q \& A", "Introduce yourself", "Tell about places" and "Greetings" [15], [18]. However, these activities are limited and designed to meet very specific outcomes such as new vocabulary learning, pronunciation of words and phrases use. Meanwhile simulation is conducted in pair with minimum two partners will give more opportunity for students to practice their language competency. In the other hand, monitoring and giving feedback become more precise in simulation compared to the group activities [drama or role play] with a large number of participants [18].

Obviously, the implementation of simulation games intended to help students learn language consciously and indirectly. Simulation is a language-oriented activity in which a student has to produce a language items (vocabulary, phrases and sentences) through speaking or writing [27]. Basically, simulation activities enable language learners to acquire language by reasoning (reading, analyzing, organizing and plotting dialogues) and indirectly such as correct pronunciation, memorization, practice and recall. This is in line with Mentalist theory and Mechanical theory in language acquisition theory [10].

\subsection{Speaking Skills Strategies}

Based on the simulation activities, students are expected to use a variety of strategies to make this process successful. Thus, Arabic language acquisition relates strongly on speaking skills which require an active TL environment. Other than that, specific strategies will only be practical when they were imposed on the right activities. Learning strategies classified into five, namely direct learning strategy, indirect learning strategy, interactive strategy, experimental strategy and self-learning strategy [9]. Therefore, looking language learning as productive oriented outcome, these strategies were narrowed into language learning strategies.

In language learning, there are generally six language learning strategies introduced by leading scholar, Oxford [22] that researchers often refer to in the Inventory of Language Learning Strategies (ILLS). Local scholars in Arabic, such as Kamarul Shukri Mat Teh et al. [32] have proposed a seventh, namely metaphysical strategy. Since this strategy is general and covers all aspects of language 
skills in addition to speaking skills (ie, reading, writing and listening), Oxford and Cohen [7], have detailed the strategy into six language skills along with items specific to each strategy. According to Nadhilah Abdul Pisal \& Kamarul Shukri Mat Teh [24], the strategies are listening (LS), vocabulary strategy (VS), speech strategy (SS), reading strategy (RS), writing strategy (WS) and translation strategy (TS). The mentioned list of the strategies is not necessarily combined in one individual; some might be highly favored while the rest is not compatible due the variety of learners' profile.

Therefore, this study focuses only on speech strategies addressed in three questions as follows:

1. What I do to practice speech

2. What do I do to talk to someone

3. What do I do when I forget a vocabulary or phrase when speaking

The above questions are adopted form Oxford \& Cohen [8] carried out as the guideline for researchers to embark on this study. Therefore, this study is not necessarily intended to respond the questions directly. However, these questions will reflect the study set up, process and the result. The illustration 1 below demonstrates how these questions functioning:

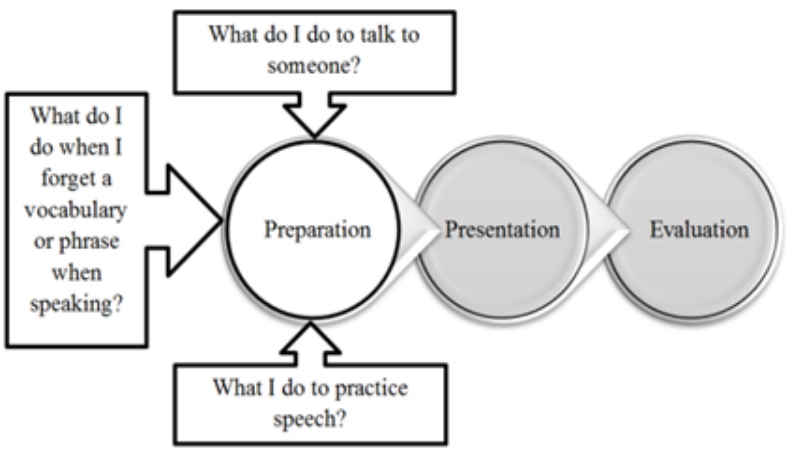

Illustration 1. Simulation Activity Process

This illustration describes the students' endeavor to begin the activity. In the preparation stage, they will keep questioning to his/her partner how to practice the right vocabularies and phrases, how to ask and how to answer, what is the best attitude/action to talk to someone. Meanwhile the backup plan is always taken into consideration if they might forget any vocabulary or phrase during presentation. In summary, any strategy used by student in simulation activity could be identified in the preparation stage and presentation stage. Thus, participants' journal notes and observation check list will work on this. Therefore, detail procedure for data collecting and analysis will be depicted in methodology section.

\subsection{An Overview on the Related Past Studies}

The issue of Arabic speaking skills has been recognized by scholars of Arabic language and education. Ahmad Syalabi [30] echoes this by pointing out that long periods of learning Arabic in non-Arab languages do not show favorable results, but in fact find Arabic to be difficult language. While Ta'imah [31] described the aspects of communication for each individual as different from other people based on differences in environment, living situation, individual characteristics, fluency of language as a means of communication, speed of communication, and other factors in language communication. This is closely related to the teaching and learning (TL) process and related matters.

As such, the Arabic language education and teaching approach is needed for immediate change in order for the Arabic language courses offered to truly benefit students' language skills. Since the emergence of communicative approach in TL of Arabic language, intensive studies were conducted on approach, methods, techniques, strategies, attitudes, contents of modules etc. However, this article will be limited to previous studies on speaking skills which have been conducted at various levels and many dimensions. This notion has a strong justification since in communicative approach speaking skills was regarded as center of language TL. Therefore, previous related studies could be stipulated from the illustration 2 :

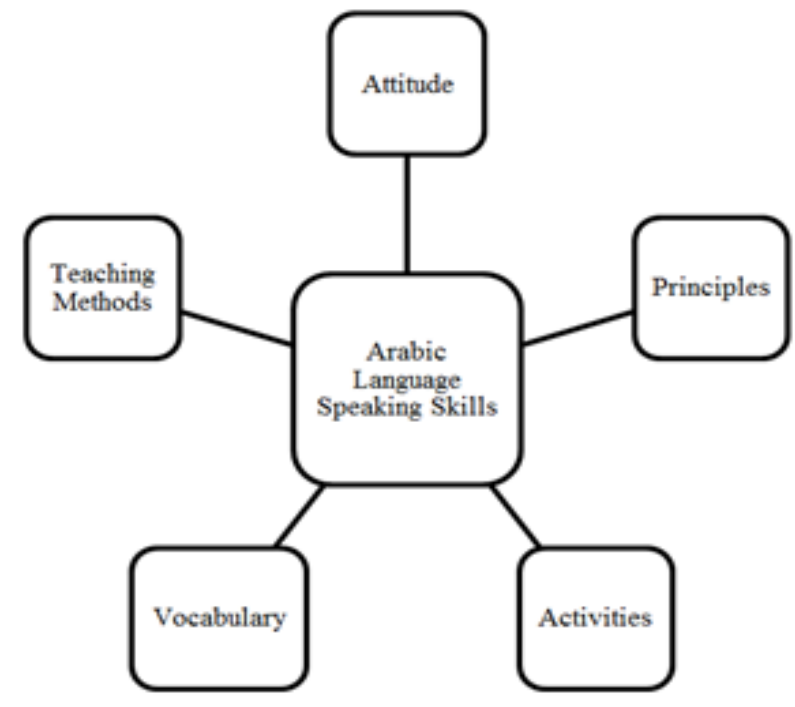

Illustration 2. Dimensions on Speaking Skills Studies for Arabic Teaching and Learning

Attitude of the language learners is a part of studies for many researchers, because attitude may determine the success of the learning process. Rahimi et al., [35] examined resource management strategies among students studying Arabic language skills. This study found that adult learners have their own ego and do not want to speak Arabic [35]. The reason is that their anxiety of their friends who have the basic language of Arabic will correct their mistakes even though they are small mistakes. These findings support the theory of learner's difference between adult and child. However, this phenomenon 
could be overcome by creating class activities that may transform negative attitude to positive one. Role play activity was proven to be positively accepted among adult learners and has capability in predicting their proficiency in Arabic speaking skills [18].

Teaching method is highly significant and has great impact on speaking skills. Academically speaking, since the emergence of communicative approach in Arabic language teaching and learning, many methods were proposed by scholars and educators in foreign language. Zawawi Ismail et al. [11] have embarked on the study of teaching methods of Arabic language. They focused on the practice of teachers teaching Arabic language in religious schools. This study found that teachers often use the 'question-and-answer', 'repetition and pronunciation' techniques to improve their Arabic speaking skills. Even these methods were acceptable, variety in class activities will be more intriguing and effective to lighten up class environment. Current studies also highlighted recent issues related to speaking skills by Masyitoh Yaacob \& Kaseh Abu Bakar [33]. This study found that there are still shortcomings in the study of oral language teaching methods. It was emphasized that studies on the teaching of Arabic language skills must continue to be explored in terms of the process of implementation of the teaching approach. The latest study on communicative approach by Zawawi Ismail et al. [12] proposed the combination of verbal and non-verbal communication must be strong to ensure successful teaching and learning. Thus, in simulation activity, students are expected to intentionally manipulate verbal and non-verbal communication for the task accordingly.

The function of vocabulary in determining language competency could not be disputed. In the theory ground, teaching and learning of language have to provide sufficient and relevant vocabularies for the learners. Four language skills will not achieve the objective if the issue of vocabulary is taken for granted. Ashinida Aladdin [2] has carried a study on vocabulary relationship with speaking performance. She mentions that the reasons leading to the weakness of the Arabic language student's language skills are that they are often unable to speak a single word or make a grammatical sentence as they wish to convey to the audience [2]. The study also found that vocabulary problems caused the students' difficulty in speaking [2]. The findings are unarguable, since the level of foreign language is based on vocabulary mastery [27]. Therefore, it was crucial for the students to enrich and master vocabulary to gain confidence when it comes to speaking skills.

Nadwah et al [23] also has conducted a qualitative study on speaking skills issues of Arabic among university students. The study found that $70 \%$ of students are unable to follow in-depth discussions classes effectively due to their poor acquisition of Arabic. The difficulties in speaking Arabic have been restricting students' ability in activities that require speaking skills such as oral presentation. In addition, the lack of vocabulary also interferes with the smoothness on their performance in speaking activities.

It was known that language activities make a great contribution to giving student an opportunity to acquire language skills in enjoyable manners. Thus, determining an appropriate activity requires teachers to select the activity which can meet the objective of learning outcomes. Raja Hazirah Raja Sulaiman et al. [29] conducted a study on the impact of role play on Arabic language skills. According to the students who participated in this activity, the positive response was that the confidence to speak Arabic was increasing and the vocabulary of Arabic was enriched [29]. Whereby Azman et al. [18] carried out the study on the role play among students and their attitude towards the activity. The findings of the study suggested that student's positive attitude toward role play activity will enhance their performance in Arabic learning, especially speaking skills [18]. As mentioned by Wildi and Titin [1], grammatical aspect such as gender agreement is one of the most problematic in oral production. However language activity may reduce the problem when it comes into practice.

Study carried out by Asrori, I. [4], reinforces the view that oral skills are a benchmark of one's speaking skills. In order to achieve the purpose of speaking skills, he has introduced three basic principles, namely the ability to distinguish sounds, find meaning and understand expressions [4]. These principles could be elaborated to mental processes such as understanding, responding, matching, adjusting and responding [21]. It was also suggested that language learners must be encouraged and motivated to build their confidence using Arabic in their speech. As Goh and Azman [28] asserted, speaking skills are productive activity, and it required language learners to participate actively in producing language use, and this can be realized through simulation.

This current study is particularly significant in term of improving the quality of Arabic teaching and learning. The main goal of the Arabic language is to develop oral communication skills among Arabic language learners. Therefore, the implementation of simulation activities is beneficial for teachers and students if they can utilize the activity effectively and successfully.

\section{Methodology}

\subsection{Research Context}

This study uses fully qualitative approach. Based on this category, data interpretation will not use numerical presentation and no statistical application will be involved. Therefore, the instrument of this study is the researcher himself who is responsible for observing, recording and 
evaluating. The study has carried out two phases for data collection, namely journal notes and observation checklist.

\subsubsection{Phase 1}

Journal Notes: Four faculty members were asked to record their observations before and after the simulation tests were conducted. To ensure usability of the notes, three criteria were outlined to record intended information. Firstly, this note provides useful data for researchers to identify strategies used by students to master speaking skills. Secondly, each group involved must be observed regardless of their genders and level of proficiency. Therefore, no specific criteria imposed to give them more freedom to jot down any useful information that attracted their observation. Finally, the notes must provide some opinion by the observer regarding the observation with their own perspective and expertise.

\subsubsection{Phase 2}

Observation Check List: 12 students were involved as participants. They were Arabic language learners in UiTM Terengganu March-July 2019 semester of study. They come from third level Arabic language in the degree program (TAC501). The concentration on this particular group has a fair justification considering the participants has passed two levels which expected to be more proficient compared to first and second level groups.

Study Procedure: The students involved are given one task, one (1) minute simulation. Upon completion of the presentation, the researcher will list down any language errors (phonetic, morphological, syntactic and pragmatic) and make corrective suggestions. Subsequently when the actual test of the simulation is performed, then the scores obtained by the study participants will be evaluated with notes also made during the simulation. Therefore, in this study, this group was considered as controlled group.

\subsection{Analysis}

Descriptive-inductive analysis was applied in the data. Each data obtained will be scrutinized and discussed based on previous research and findings for comparison and critical analysis.

\section{Result and Discussion}

This section presents two basic findings, the first of which is a review of the lecturers' notes that refer to the students' strategies in the simulation activities. The second is the findings of the students' simulation assessments. Based on the assessment process (1) one minute and the actual test (2) two minutes, the researcher has listed some mistakes made by the participants of the study. Based on observations, the observed language errors can be categorized into lexical, grammatical and pragmatic use.
Based on the notes of the Arabic language lecturers, the study has found a theme that focuses on the learning strategies used by the Arabic language learners. This is explained as follows:

\section{Memorizing Strategies:}

The fact of remembering or memorizing is the most fundamental stage in the theory of learning. This can be attributed to Bloom's [6] Taxonomic theory of 'memory,' which aims to remember and memorize as the basis of learning. In this simulation activity, the study found that the informant involved noted that remembering was a powerful strategy, in that all students agreed to use this strategy to prepare the simulation task. But the level of students practicing this strategy is as different as the following: "Some students memorize the simulation dialog well." $\{$ Inf.1\}. This statement is supported by the following informant note "Most students were found to be able to remember simulated texts well, fluently and clearly" $\{$ Inf. 4\}. The informant added that "Students are found to be able to memorize texts well and translate ideas through clear and fluent speech."

Based on this situation, the lecturers have given students time to reflect on their memory as follows: "I give 20 to 30 minutes to build the text of the conversation and memorize it." $\{\operatorname{Inf} .2\}$. The same is said by the informant regarding the process of remembering the text experienced by his students. He notes: "They do not have enough time to memorize ..." which is why "lecturers have to wait for them to memorize a few moments before they make a presentation" $\{$ Inf. 3$\}$.

In short, memory strategies are very important for students who want to play Arabic simulation. This clearly shows that it is difficult for students to perform spontaneous simulations, especially when the Arabic language is new to them. Al-khresheh, M. H., Khaerurrozikin, A., \& Zaid, A. H. [3] have mentioned among the essential factors to communicate effectively in Arabic language is an ability to memorize maximum numbers of vocabulary. Therefore, many techniques are proposed to enhance student memorization such as drilling, question \& answer and chorus exercise [16]. These techniques can be imposed on students by themselves or supervised by their lecturers before the simulation presentation. The study was carried out by Rosni et al. [26] on debater trainers. Specifically, the role of trainers is confirmed to ensure the success of the debaters through three approaches namely collecting resources, reinforcement and application. In this regards, reinforcement is crucial to help student memorize the appropriate vocabulary, phrase and sentence structure.

\section{Writing Strategies:}

The writing strategy defined here as how students first 
write scripts that will be used for simulation activity purposes. The facilitators were found to guide the students to write simulated scripts, either by supervision (i.e. students formulate dialogues and then get advice and correct mistakes) or the facilitators provided a general draft and students developed their own dialogues according to the needs of their simulation partners.

The informant's note shows students using this strategy as follows: "Almost all were diligent in making the text (talking, asking lecturers, asking other friends) \{Inf. 1\}. Even this writing strategy is also helpful and very important for students to support their memory strategies such as the statement: “... these students just ask for some extra time to help them memorize and memorize the text of the conversation.” $\{$ Inf. 2$\}$

In preparing the script, some students provided a dialogue on grammatical aspects as noted by the informant 3: "they took verses already in the book and exchanged some elements such as examples of pronouns, exchange of verbs derivation patterns with the gender different, numbers of doer and so on. "The same was noted by informant 4 as it states: "Lecturers encourage students to add simulated text by referring to the learning in the textbook."

Based on this writing strategy, students can practice their Arabic grammar skills, especially with the guidance of lecturers. As can be seen from the analysis of the errors in the next section, there are still grammatical errors made by the students. But these aspects of error are actually detectable and can be improved by suggesting specific techniques in grammar teaching.

\section{Reading Strategy:}

The intended reading strategy can be viewed from the first two angles, where students read the dialogue text repeatedly to support the memory strategy and the second is that students use notes to help them carry out actual simulation activities. In fact, when a student is reading during the simulation activity, it is highly unlikely that the student will not use the memory strategy or will not be able to use it effectively.

The lecturer guides the students to read the text to ensure the correct pronunciation and style as noted: "Next, the lecturer asks the student to read the text in large numbers to facilitate the pronunciation of the student" \{Inf.4\}. Such exercises are practical if students use the same script for simulation activities. But as students develop this dialogue themselves, then the guidance of the lecturer is crucial to helping them read it correctly before remembering which dialog to use.

On the other hand, reading strategies give a negative message that students cannot speak well. This is clearly noted by the four informants in this study:

a. $\quad$ "Some students don't even memorize, just look at the paper and read it." $\{$ Inf. 1$\}$ b. "The third group is a simple group that is, occasionally looking at the text during the presentation and the level of fluency and pronunciation" $\{$ Inf. 2$\}$

c. " "... Bring scripts or hold a phone with a picture of the script during the simulation process.” [Inf. 3]

d. "There are also students who do not remember the text and have to look at the text during the simulation test" $\{$ Inf. 4$\}$

Based on this strategy, the researcher looks at it from a positive angle, which is why it is effective for students to read to help them remember difficult or newly learned words / words. As such, this reading technique can be useful as it helps to recall and support students' self-confidence during activity.

Then the second phase of the study is conducted through observation checklist on the linguistic items for student's production during simulation presentation. Researchers have classified this matter with concentrating on erroneous into two, lexical preference and phrase structure.

1. The lexical and morphological error occurs in three aspects:

a) Lack of awareness/unable to differentiate between the use of Arabic verbs for male and female. The student memorizes only one word for a meaning such as تسكن- تمارس which means 'you live' and 'you practice' $<\mathrm{P} 01>$. The correct use of this lexical is تسكنين- تمارسين with the same meaning but with reference to the female gender. The same applies to تفضل, تحب>P10> used in masculine patterns, although it refers to the feminine in the actual context. In addition, misspelled pronouns also caused students to rely on their own

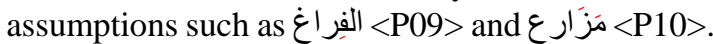

b) Unable to use the correct verb conjugation

It occurs in phrases such as: >P01> نحن لعبe

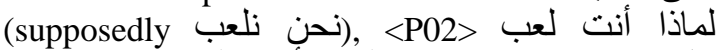

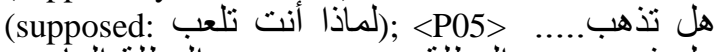

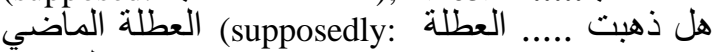
(الماضي

c) Lack of awareness/unable to differentiate between word classes (verb and verbal noun)

It occurs in phrases such as أنا صلاة الضحى >P04> (أنا أصلى صلاة الضحى (supposedly); 'I make a revision' is stated in أنا مر اجعة أنعاة >P05> (supposedly: (أنا أراجع and 'Because he read the book' is

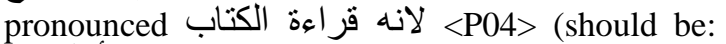

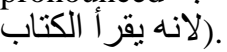

\section{Phrase structure}

Students are also unable to use possessive phrase and adjective phrase in correct structure. The pattern of Idafah (possession) is expressed in conjunction with a definite marker such as القريتى P01> or an adjective pattern not identical to an object of the genus aspect like قريتي جميل 
> P04> which is supposed to be قريتي جميلة.

This observation checklist has demonstrated what really occurs during simulation activity regarding linguistic aspect and learning process. Limited lexical preference will lead students to the mistake, even certain lexical has the right meaning, but the use is incorrect because the respondent only memorize one pattern of the lexical while in fact he/she should be aware that the same lexical owns several patterns accordingly to the context.

\section{Conclusions}

In general, this study has successfully identified some important factors that help Arabic language learners and students to improve their acquisition of Arabic through simulation activities.

First and foremost, according to the lecturer's notes, there are three strategies that are important for students to master speaking skills in Arabic, namely, memorization, writing and reading strategies. Considering these strategies, researcher must work simultaneously in the process of improving students' Arabic speaking skills. Researchers recommend that this reading strategy can be developed creatively among students in particular to provide appropriate material for students to read by concentrating on the useful phrases for communication. The features should be interesting, concise, accurate, and not entirely informative in the script.

This study was able to identify aspects of common error experienced by students such as lexical selection, morphological and grammatical aspect. This study also found that lack of vocabulary will contribute to the student's inability to speak in Arabic. As a result, students end up memorizing the sentences rather than to speak the language spontaneously. Even the memory strategies are good especially at the very earliest stages of learning, but students should be encouraged to be familiar with the words and have wider chance to use the vocabularies in various activities.

Similar to the finding of previous studies [33], [2], [23], the result of the study shows that students still need effective guide and techniques to help them understand basic Arabic formulas over time. It is hoped that with sufficient vocabularies and correct application of grammatical knowledge in speaking activities, students can express their ideas and communicate fluently according to their language level.

It is obvious that much still needs to be done by Arabic language researcher to investigate the effectiveness of various teaching and learning strategies to enhance Arabic speaking skills among students. Based on this particular finding, researchers assume that future research could be benefited by extending these investigations of simulation activities through variety of tasks that include a variety of speech patterns, such as spontaneous speech, or more extended discourse such as narration, description, exposition, and argument.

\section{Acknowledgements}

This study is under a registered research grant (SIG) (600-UiTMCTKD (PJI / RMU / SS / DANASIG5 / 2/1) Jld.4 Dss (13/2019)

\section{REFERENCES}

[1] Adila, W., \& Ma'mun, T. N, Knowledge and Use of Grammar among Indonesian Second Language Learners of Arabic: Focus on Grammatical Gender Agreement, Universal Journal of Educational Research, Vol. 8, No.2, 709-722, 2020.

[2] Aladdin, A., Analisis Penggunaan Strategi Komunikasi dalam Komunikasi Lisan Bahasa Arab, GEMAOnline ${ }^{\circledR}$ Journal of Language Studies, Vol. 12, No. 2, 645-666, 2012.

[3] Al-Khresheh, M. H., Khaerurrozikin, A., \& Zaid, A. H., The Efficiency of Using Pictures in Teaching Speaking Skills of Non-native Arabic Beginner Students. Universal Journal of Educational Research, Vol. 8, No. 3, 872-878, 2020.

[4] Asrori, I., Pembelajaran Kemahiran Lisan Bahasa Arab. Prosiding Konfererensi Nasional Bahasa Arab, Vol. 4, No. 4, 166-175, 2018

[5] Batuto, L. A., \& de la Pena, M. M. E. (2019). Enhancing Students' Speaking Competence Through Communicative Language Teaching Method, International Journal of Recent Advances in Multidisciplinary Research, Vol. 6, No. 8, 5107-5117, 2019

[6] Bloom B. S., Taxonomy of Educational Objectives, Handbook I: The Cognitive Domain. David McKay Co Inc., New York, 1956

[7] Brown, H.D., Teaching by Principles: An Interactive Approach to Language Pedagogy (2 second Edition), Addison Wesley Longman, Inc., New York, 2001

[8] Cohen, A.D. \& Oxford, R.L., Young Learners' Language Strategy Use Survey, Online available from http://www.carla.umn.edu/about/profiles/CohenPapers/You ng_Lg_Strat_Srvy.html, 2002

[9] Hamruni, M.Si, Strategi Pembelajaran, Insan Madani, Jogjakarta, 2012.

[10] Husin, K,. Perkaedahan Mengajar Bahasa, Kumpulan Budiman Sdn. Bhd., Kuala Lumpur, 1995

[11] Ismail, Z., Tamuri, A. H., Yusoff, N. M. R. N., \& Othman, M. A. U., Teknik Pengajaran Kemahiran Bertutur Bahasa Arab di SMKA di Malaysia, GEMA Online ${ }^{\circledR}$ Journal of Language Studies, Vol. 11, No. 2, 67-82, 2011.

[12] Ismail, Z., Halias, N., Md Saad, R., \& Mohamed, M. F. Motivation as the Mediator in Relationship between Non-verbal Communication of Arabic Language Teachers and Student Learning Outcomes. Universal Journal of Educational Research, Vol. 8, No. 2, 700-708, 2020. 
[13] Javid, C. Z., an Investigation of Effectiveness of Simulation in Developing Oral Skills: A Case Study, European Scientific Journal, Vol. 9, No. 32, 2013.

[14] Kayi, H., Teaching speaking: Activities to Promote Speaking in a Second Language. Новейшие научные достижения, Vol. 12, No. 2012, 2012.

[15] Khalilullah, M., Media Pembelajaran Bahasa Arab, ASWAJA Pressindo, Jogjakarta, 2012.

[16] Mamat, W. H. W. \& Abdullah, N. M. T., Permainan dan Simulasi, Dewan Bahasa Dan Pustaka, Kuala Lumpur, 2015.

[17] Maromar, F., Ismail, M. R., Ghazali, A. R., Fauzi, M. S. H. M., Othman, K. A. A., Rahman, M. A. A. \& Basit, N. F. A., Teknik Meningkatkan Kemahiran Bertutur Bahasa Arab dalam Kalangan Bukan Penutur Jati di Ipts dan Ipg, 5th International Research Management \& Innovation Conference, Palm Garden Hotel, Putrajaya, 2018.

[18] Mat, A. C., Awang, A., Nokman, A. Z., Musilehat, N. S., Bakar, A. F. A., \& Yusoff, M. S. A., Investigating Attitude towards Role Play and Its Subjective Value in Predicting Arabic Language Proficiency among UiTM Students, International Journal of Education, Vol. 7, No. 4, 334-346, 2019.

[19] Mujib, F. \& Rahmawati, N., Metode Permainan-Permainan Edukatif dalam Belajar Bahasa Arab, DIVA Press, Jogjakarta, 2011.

[20] Nair, M. A., Teaching English as a Foreign Language, Utusan Publications \& Distributors Sdn. Bhd., Kuala Lumpur, 2000

[21] Noor, S. S. M., Hat, N. C. \& Gaza, N., Penilaian Kemahiran Bertutur dalam Bahasa Arab Melalui Kaedah Aktiviti Bahasa. In Kamarul Shukri Mat Teh, Zulazhan Ab. Halim, Mohd Shahrizal Nasir \& Nurazan Mohmad Rouyan. Dinamika Pendidikan Bahasa Arab: Menelusuri Inovasi Profesionalisme Keguruan. Universiti Sultan Zainal Abidin: Penerbit UnisZA. pg. 99-114, 2012.

[22] Oxford, R.L., LanguageLlearning Strategies: What Every Teacher Should Know, Heinle \& Heinle, Boston, 1990..

[23] Pisal, N. A., \& Daud, N., Permasalahan Pertuturan Dalam Bahasa Arab Sebagai Bahasa Kedua, GEMA Online ${ }^{\circledR}$ Journal of Language Studies, Vol 14, No.1,117-133, 2014

[24] Pisal, N. A., \& Teh, K. S. M., Perbezaan Jantina Dalam Penggunaan Strategi Pembelajaran Kemahiran Berbahasa Arab. Journal of Nusantara Studies 2018, Vol. 3, No. 1,
143-153, 2018.

[25] Rohman, F., Metodologi Pembelajaran Bahasa Arab. Madani, Malang, 2015

[26] Samah, R., Hamid, M. F. A., Sha’ari, S. H., \& Mohamad, A. H., Aktiviti Pengajaran Kemahiran Bertutur Bahasa Arab Dalam Kalangan Jurulatih Debat, GEMA Online ${ }^{\circledR}$ Journal of Language Studies, Vol. 13, No. 2, 2013.

[27] Samah, R., Kaedah Pengajaran Kosa Kata Bahasa Arab untuk Pelajar Bukan Arab, Penerbit USIM, Universiti Sains islam Malaysia, 2013.

[28] Soon, G. Y. \& Mat, A. C., Panduan Strategi Belajar Bahasa Asing, Penerbit UiTM (UPENA), Shah Alam, Malaysia, 2010

[29] Sulaiman, R. H. R., Din, N. M. N., Awang, R. E. N., Mustafa, Z., Noruddin, N., \& Talib, M. T., Role-playing Technique in Teaching Arabic Communication: A Case Study at Universiti Sultan Zainal Abidin in Malaysia, International Journal of Academic Research in Business and Social Sciences, Vol. 7, No. 10, 309-318, 2017.

[30] Syalabi, A., Ta'lim al-Lughah al-'Arabiyyah li Ghayr al-`Arab, Maktabah al-Nahadah al-Misriyyah, Cairo, 1980

[31] Ta‘imah, R. A., Ta'lim al-‘Arabiyyah li ghayr al-natiqīna bihā: manāhijuhu wa asālibuhu, al-Munazzamah al-Islamiyyah li-al-Tarbiyah wa al-‘ulum wa al-Thaqafah (ISESCO), Ribath, 1989.

[32] Teh, K. S. M., Embi, M. A., Yusoff, N. M. R. N., \& Mahamod, Z., Strategi Metafizik: Kesinambungan Penerokaan Domain Strategi Utama Pembelajaran Bahasa Language. GEMA Online ${ }^{\circledR}$ Journal of Language Studies, Vol. 9, No. 2, 2009.

[33] Yaacob, M., \& Bakar, K. A., Tinjauan Literatur Pengajaran Kemahiran Bertutur Bahasa Arab, BITARA International Journal of Civilizational Studies and Human Sciences, Vol. 1, No. 2, 015-025, 2018

[34] Yen, Y. C., Hou, H. T., \& Chang, K. E., Applying Role-playing Strategy to Enhance Learners' Writing and Speaking Skills in EFL Courses Using Facebook and Skype as Learning Tools: A Case Study in Taiwan, Computer Assisted Language Learning, Vol. 28, No. 5, 383-406, 2015.

[35] Yusri, G., Rahimi, N. M., Shah, P. M., Wah W. H. \& Sahrir, M. S., Penggunaan Bahasa Arab Lisan dan Hubungannya dengan Strategi Pengurusan Sumber, GEMA Online ${ }^{\circledR}$ Journal of Language Studies, Vol. 12, No. 2, 505-520, 2012. 